\title{
Will the Stress Tests for Banks Improve the Stability of Financial Markets?
}

The European banking system is resilient to adverse shocks as long as the European taxpayer continues to support it. This is the main message after the stress tests of $91 \mathrm{EU}$ banks. The tested banks represent $65 \%$ of the European market in terms of total assets. ${ }^{1}$ The results are better than many experts had expected. The Tier 1 capital ratio (primarily common stock, reserves or retained earnings to risk weighted assets) of all banks would decrease in the most severe scenario from $10.3 \%$ in 2009 to $9.2 \%$ by the end of 2011 . Only seven banks would fail the $6 \%$ threshold established for the tests, and the estimated need for an additional $€ 3.5$ billion in capital funds is quite moderate.

However, it is clear that to a large degree the revealed resilience is due to the European taxpayer. More than $40 \%$ of the tested banks received capital injections from their national or regional governments before the stress tests. EU-wide government capital support amounts to $€ 197$ billion, accounting for 1.2 percentage points of the aggregate Tier 1 capital ratio. The distance between the starting Tier 1 capital ratio and the $6 \%$ threshold was large for many banks simply because of taxpayer assistance.

It is also a fact that EU bank exposure to European sovereign debt is large. During the crisis, banks transferred many of these bonds from the trading book to the banking book. Bonds in the banking book are assumed to be held to maturity. Because of that, loan loss provisions can be avoided, even if an increase in the risk premium and a corresponding loss in the value of the bonds occur. Loan loss provisions in the banking book are due if, and only if, the sovereign debtor goes bankrupt. However, the EU established the $€ 440$ billion European Rescue Fund in order to avoid such an event. This commitment to rule out sovereign bankruptcy enabled the Committee of European Banking Supervisors (CEBS) to exclude the possibility of state default from the various stress scenarios. Consequently, the stress scenarios left large parts of the exposure to European sovereign debt unaffected, and the European banking system appeared sound. There is no doubt, however, that this soundness rests on the taxpayers' shoulders. Most likely, the results would have been very different if at least one scenario tested the health of banks without the public capital support.

What will financial markets conclude from the results of the stress tests? The major stock markets gained after the publication of the stress test results. Risk premia for credit insurance contracts fell. Additionally, the overnight deposit facility of the European Central Bank, which is considered to be an indicator of the degree of confidence among banks, has decreased since the European debt crisis in May and remains at moderate levels. Thus, in the short term, it seems that capital markets reacted favourably to the results of the stress tests. However, it is difficult to identify the reason for this reaction. On the one hand, market participants could simply be relieved that officials have stated, on paper, that the European banking system is sound, and thus the huge uncertainty caused by speculation about the outcome and transparency of the stress scenarios has finally evaporated. On the other hand, the observed improvements in the financial markets after the stress tests could signal that trust in the European banking system is starting to come back. Only in the second case would the stress tests improve the stability of financial markets in the long term. Thus, determining whether the stress tests can be considered an exercise in strengthening long-term trust is crucial.

Long-term trust depends on several conditions. First, the reliability of the stress tests is important. Secondly, regulators need to continue reforming the architecture of the European fi-

1 CEBS Press Release, http://www.c-ebs.org/EuWideStressTesting.aspx. 
nancial market independent of the stress tests and their results. Thirdly, and most importantly, markets must be confident about the ongoing governmental support for the banking system in the medium term. Markets also need to believe that in case of governmental retreat, private capital markets will be able to step in. After all, bank shares offered by governments only have a chance of receiving fair valuation if market demand is sufficient.

The stress tests themselves have a credit side and a debit side. The CEBS's proven ability to coordinate the exercise EU-wide is clearly on the credit side. The CEBS gained authority and presented itself as the nucleus of a potentially powerful EU-wide regulatory agency providing supervision for banks. The bank-by-bank publication of all sovereign debt holdings (both trading and banking book) revealed the total exposure to vulnerable European states. Furthermore, capital markets now have an idea as to how much additional capital European banks need at minimum in the short term, and the banks learned that the minimum regulatory Tier 1 capital ratio (4\% at present) will likely be increased soon. Several shortcomings of the stress scenarios are on the debit side. The financial crisis originated from a slump in housing markets and the subsequent drain on banks' liquidity. Excessive leveraging of banks contributed to balance sheet inflation and to the too-big-to-fail phenomenon. The Lehman bankruptcy brought the banking system to the brink of a worldwide breakdown. Given these facts, it is surprising that regulators ignored the consequences of a further deterioration of European housing markets, that bank defaults were excluded from the scenarios, and that the impact of adverse scenarios on banks' liquidity and leverage ratios was neglected. Moreover, systemically relevant banks have become increasingly active in commodity markets in recent years. However, regulators failed to test for the consequences of a strong decrease in commodity prices. In sum, some uncertainty was reduced, but the important aspects omitted from the stress tests may endanger their reliability and, consequently, capital markets' trust in the European banking system.

In general, stress tests can only describe problems but not remove them. Therefore regulatory complacency after the tests would be especially detrimental to the long-term stability of capital markets. The agenda for improving the financial markets' architecture is still huge. Most importantly, the international community needs to finally agree on strict and uniform capital rules for banks. At the same time, national regulators have to do their homework and make progress in fixing the structures of the domestic banking systems. For example, the German government should take the weak stress results of some Landesbanks as a strong reminder that the merging of these ailing public banks is overdue. More transparency regarding banks' holdings of toxic assets is also necessary, and the number of bad banks in Europe has to be increased. After all, the cleaning of banks' balance sheets is essential for long-term trust building. Another important regulatory issue that has to be promoted is the establishment of a unified European supervisory agency with the power to enforce regulatory rules. Fortunately, the performance of CEBS in coordinating the stress tests has clearly revealed that such an institution could work successfully despite national egoism.

Finally, if European governments tried to exit banks in the near future, the most likely result would be an immediate deterioration in capital market conditions. At the same time, the European debt crisis made clear that governments eventually need their money back. Thus, taxpayer patience with the still struggling European banking system is the most crucial factor in the trust-building process of capital markets. Capital markets will stabilise if, and only if, governments are prepared to further support European banks and to put better regulatory rules quickly into place. The latter is absolutely necessary to increase confidence in the long-term stability of the European banking sector. More stability will eventually translate into a higher demand for bank stocks, thus allowing governments to recoup their investments in the banks. 